\title{
Large seismic faults in the Hellenic arc
}

\author{
Basil C. Papazachos \\ Geophysical Laboratory, University of Thessaloniki, Thessaloniki, Greece
}

\begin{abstract}
Using information concerning reliable fault plane solutions, spatial distribution of strong earthquakes $\left(M_{s} \geq 6.0\right)$ as well as sea bottom and coastal topography, properties of the seismic faults (orientation, dimension, type of faulting) were determined in seven shallow $(\mathrm{h}<40 \mathrm{~km})$ seismogenic regions along the convex part of the Hellenic arc (Hellenic trench) and in four seismogenic regions of intermediate depth earthquakes $(\mathrm{h}=40-100 \mathrm{~km})$ along the concave part of this arc. Except for the northwesternmost part of the Hellenic trench, where the strike-slip Cephalonia transform fault dominates, all other faults along this trench are low angle thrust faults. In the western part of the trench (Zante-west Crete) faults strike NW-SE and dip NE, while in its eastern part (east Crete-Rhodos) faults strike WNW-ESE and dip NNE. Such system of faulting can be attributed to an overthrust of the Aegean lithosphere on the eastern Mediterranean lithosphere. The longest of these faults $(L=300 \mathrm{~km})$ is that which produced the largest known shallow earthquake in the Mediterranean area (21 July 365, $\left.M_{s}=8.3\right)$ which is located near the southwestern coast of Crete. The second longest such fault $(L=170 \mathrm{~km})$ is that which produced a large earthquake (December 1303, $M_{s}=8.0$ ) in the easternmost part of the trench (east of Rhodos island). Both earthquakes were associated with gigantic tsunamis which caused extensive damage in the coast of many Eastern Mediterranean countries. Seismic faults of the intermediate depth earthquakes in the shallow part of the Benioff zone $(\mathrm{h}=40-100 \mathrm{~km})$ are of strike-slip type, with a thrust component. The orientations of these faults vary along the concave part of the arc in accordance with a subduction of remnants of an old lithospheric slab from the convex side (Mediterranean) to the concave side (Aegean) of the Hellenic arc. The longest of these faults $(L=220 \mathrm{~km})$ is that which produced the largest known intermediate depth earthquake in the whole Mediterranean area (12 October 1856, $M=8.2$ ) north of Crete. The second longest such fault $(L=160 \mathrm{~km})$ produced a large earthquake (26 June 1926, $M=8.0$ ) in the easternmost part of the concave part of the arc (near Rhodos). Both earthquakes caused very serious damage in several Eastern Mediterranean countries but were not associated with tsunamis.
\end{abstract}

Key words Hellenic arc - seismic fault

\section{Introduction}

The Hellenic arc is one of the most prominent tectonic features of the Mediterranean area. It has most of the characteristics of the island arcs, such as an oceanic trench, in its con-

Mailing address: Prof. Basil C. Papazachos, Geophysical Laboratory, University of Thessaloniki, GR-54006, Thessaloniki, Greece; e-mail: ritsa@geo.auth.gr vex side (Hellenic trench), a sedimentary arc, as well as a volcanic arc and a marginal sea (Aegean) in its concave part.

Its shallow and intermediate depth seismic activity is high with earthquakes which reach magnitude eight or so. A Benioff seismic zone, which was identified about three decades ago (Papazachos and Comninakis, 1969, 1971), is dipping from the convex side of the arc (Eastern Mediterranean) to its concave part (Aegean).

Although much work has been done on the active tectonics of this area (Papazachos and Comninakis, 1971; McKenzie, 1978; LePichon 
and Angelier, 1979, among many others), several relevant problems are still unsolved. One such problem is the identification (location, orientation, properties) of the faults of the big shallow and intermeditate depth earthquakes which occur in the convex and concave part of the arc, respectively.

The identification and investigation of the properties of these faults are difficult because the return periods of their large earthquakes are long and no such earthquakes occurred very recently to be investigated by data based on modern instrumentation. Further difficulties arise from the fact that the surface expressions of the rupture zones of the shallow earthquakes are in the bottom of the Eastern Mediterranean sea and rupture zones of the intermediate depth earthquakes are deep in the lithosphere under the Aegean sea.

In the present paper, the spatial clustering and delineation of the epicenters of relatively recent strong earthquakes (1800-1995, $M_{s} \geq 6.5$; 1911-1995, $M_{s} \geq 6.0$ ), sea bottom and coastal topography as well as historical macroseismic information are used to identify faults where known large earthquakes $\left(M_{s} \geq 8.0\right)$ have already occurred or probable faults of such earthquakes for which no historical information is available. Almost all such seismological data have been published (Papazachos and $\mathrm{Pa}$ pazachou, 1989) and only minor changes were made on the basis of some new information.

Investigations of the properties of these big faults are mainly based on reliable fault plane solutions of moderate shocks $\left(M_{s} \geq 5.3\right)$ which occurred in the arc during the last three decades (Papazachos and Kiratzi, 1995a,b). The available fault plane solutions of the earthquakes which occurred in each large fault belt were used to determine a typical solution for the belt by a method which is based on seismic moment summation (Papazachos and Kiratzi, 1992). Then, from the two nodal planes, the one which strikes parallel to the trend of the epicenter clustering was considered the typical fault for this region.

The convex side of the Hellenic arc is separated into seven fault regions of shallow earthquakes and the seismotectonic properties of each region are investigated with emphasis on the seismogenic regions of the two largest known earthquakes (21 July $365, M_{s}=8.3$; December $\left.1303, M_{s}=8.0\right)$. Also, the shallow part of the Benioff zone is separated into four seismogenic regions of intermediate depth earthquakes $(\mathrm{h}=40-100 \mathrm{~km})$ and their seismotectonic properties were also investigated with emphasis on the seismogenic regions of the two largest known earthquakes which occurred in this zone (12 October 1856, $M_{s}=8.2 ; 26$ June $\left.1926, M_{s}=8.0\right)$.

\section{Faults in the Hellenic trench}

The Hellenic trench consists of a series of linear depressions of the crust in the northernmost central part of the Eastern Mediterranean sea. Its water depth reaches $4 \mathrm{~km}$ in several places and in some places $5 \mathrm{~km}$. It parallels the Hellenic arc, as it starts from the southern part of the Ionian islands (west of Zante island), where the Cephalonia transform fault terminates (Scordilis et al., 1985), and continues along the convex side of the arc (south of Peloponnese-south of Crete-south of Karpathos and Rhodos) up to Rhodos where it changes direction and trends northwest-southeast, that is, parallel to the southwestern coast of Anatolia (Turkey).

Shallow earthquakes $(\mathrm{h}<40 \mathrm{~km})$ with magnitudes up to about eight or larger, which occur landward of the trench, caused extensive damage in many Eastern Mediterranean countries (Greece, Turkey, Cyprus, Israel, Egypt, Lybia, Italy, etc.) especially by the gigantic tsunamis generated by these earthquakes. Two such earthquakes are known from historical information, the 21 July 365 A.D. earthquake $\left(M_{s}=8.3\right)$ which occurred in the western part of the trench and the December 1303 earthquake $\left(M_{s}=8.0\right)$ which occurred in the easternmost part of the trench. Spatial distribution of strong well defined earthquakes of the last two centuries, fault plane solutions of recent strong shocks and sea bottom and coastal topography are used here to determine the basic properties of the two large faults where these earthquakes occurred. Such data are also used 
to examine the seismotectonic properties of the remaining part of the Hellenic trench.

In table I, information is given for the following sample of shallow mainshocks ( $\mathrm{h}<40 \mathrm{~km}$ ) which occurred during the last two centuries in the Hellenic trench:

$$
\begin{aligned}
& 1801-1995, M_{s} \geq 6.5 \\
& 1911-1995, M_{s} \geq 6.0 .
\end{aligned}
$$

This table includes all known mainshocks (no foreshocks or aftershocks) with $M_{s} \geq 6.5$ which have occurred since 1801 in the Hellenic trench and all mainshocks with $M_{s} \geq 6.0$ which occurred there during the instrumental period, because reliable seismographs have been in continuous operation since 1911 in Greece. Information for the 365 and 1303 large earthquakes are also given in this table.

Figure 1 is a map of the area where the epicenters of the earthquakes listed in table I are shown. In the same map, the isobaths of $2000 \mathrm{~m}, 3000 \mathrm{~m}$ and $4000 \mathrm{~m}$ are shown. On the basis of the above mentioned data, the whole belt is separated into the following seismogenic regions: A) Cephalonia; B) Zante; C) southwest of Peloponnese; D) west of Crete; E) southeast of Crete; F) south of Karpathos; and G) east of Rhodos. These regions are investigated separately.

A) Cephalonia transform fault region This region is dominated by the Cephalonia dextral strike slip fault (Scordilis et al., 1985) which has a length of about $L=100 \mathrm{~km}$ where earthquakes with magnitudes up to about 7.5 can occur. There are other smaller faults in this region which are parallel to the large one and are of the same type. The separation of this region from the Leukada region to the north and from the Zante region to the southeast is based on the fact that the available fault plane solutions show strike-slip faulting in Cephalonia and thrust faulting in Leukada and Zante. On the basis of four reliable fault plane solutions, the following parameters were calculated (Papazachos et al., 1994) for the typical fault
Table I. Data on the shallow earthquakes in the

\begin{tabular}{|c|c|c|c|}
\hline Date & Epicenter & $M_{s}$ & Region \\
\hline 21.07 .365 & $35.2^{\circ} \mathrm{N}, 23.2^{\circ} \mathrm{E}$ & 8.3 & $\mathrm{D}$ \\
\hline--.12 .1303 & $36.1^{\circ} \mathrm{N}, 29.0^{\circ} \mathrm{E}$ & 8.0 & $\mathrm{G}$ \\
\hline 03.07 .1805 & $35.1^{\circ} \mathrm{N}, 24.0^{\circ} \mathrm{E}$ & 7.2 & $\mathrm{D}$ \\
\hline--.12 .1815 & $34.9^{\circ} \mathrm{N}, 25.6^{\circ} \mathrm{E}$ & 6.7 & $\mathrm{E}$ \\
\hline 29.12 .1820 & $37.8^{\circ} \mathrm{N}, 21.1^{\circ} \mathrm{E}$ & 6.7 & B \\
\hline 30.08 .1840 & $37.9^{\circ} \mathrm{N}, 20.9^{\circ} \mathrm{E}$ & 6.7 & $\mathrm{~B}$ \\
\hline 28.02 .1851 & $36.3^{\circ} \mathrm{N}, 28.6^{\circ} \mathrm{E}$ & 7.2 & G \\
\hline 14.03 .1862 & $38.4^{\circ} \mathrm{N}, 20.5^{\circ} \mathrm{E}$ & 6.6 & $\mathrm{~A}$ \\
\hline 06.02 .1866 & $36.0^{\circ} \mathrm{N}, 23.0^{\circ} \mathrm{E}$ & 6.8 & $\mathrm{D}$ \\
\hline 04.02 .1867 & $38.2^{\circ} \mathrm{N}, 20.4^{\circ} \mathrm{E}$ & 7.2 & A \\
\hline 20.09 .1867 & $36.5^{\circ} \mathrm{N}, 22.3^{\circ} \mathrm{E}$ & 7.1 & $\mathrm{C}$ \\
\hline 22.02 .1870 & $36.4^{\circ} \mathrm{N}, 28.8^{\circ} \mathrm{E}$ & 6.8 & G \\
\hline 27.08 .1886 & $37.0^{\circ} \mathrm{N}, 21.5^{\circ} \mathrm{E}$ & 7.5 & $\mathrm{C}$ \\
\hline 22.01 .1899 & $37.2^{\circ} \mathrm{N}, 21.6^{\circ} \mathrm{E}$ & 6.6 & $\mathrm{C}$ \\
\hline 11.08 .1903 & $36.0^{\circ} \mathrm{N}, 22.8^{\circ} \mathrm{E}$ & 7.4 & $\mathrm{D}$ \\
\hline 24.01 .1912 & $38.1^{\circ} \mathrm{N}, 20.8^{\circ} \mathrm{E}$ & 6.8 & A \\
\hline 30.09 .1913 & $35.0^{\circ} \mathrm{N}, 24.0^{\circ} \mathrm{E}$ & 6.0 & $\mathrm{D}$ \\
\hline 27.01 .1915 & $38,4^{\circ} \mathrm{N}, 20.7^{\circ} \mathrm{E}$ & 6.6 & $\mathrm{~A}$ \\
\hline 07.08 .1915 & $38.4^{\circ} \mathrm{N}, 20.7^{\circ} \mathrm{E}$ & 6.7 & $\mathrm{~A}$ \\
\hline 24.02 .1919 & $37.3^{\circ} \mathrm{N}, 21.3^{\circ} \mathrm{E}$ & 6.3 & $\mathrm{C}$ \\
\hline 13.08 .1922 & $34.8^{\circ} \mathrm{N}, 26.5^{\circ} \mathrm{E}$ & 6.8 & $\mathrm{~F}$ \\
\hline 18.03 .1926 & $35.9^{\circ} \mathrm{N}, 29.8^{\circ} \mathrm{E}$ & 6.9 & G \\
\hline 19.09 .1926 & $36.0^{\circ} \mathrm{N}, 22.0^{\circ} \mathrm{E}$ & 6.3 & $\mathrm{D}$ \\
\hline 01.07 .1927 & $36.7^{\circ} \mathrm{N}, 22.3^{\circ} \mathrm{E}$ & 7.1 & $\mathrm{C}$ \\
\hline 20.09.1939 & $38.0^{\circ} \mathrm{N}, 21.0^{\circ} \mathrm{E}$ & 6.3 & A \\
\hline 30.08 .1947 & $35.1^{\circ} \mathrm{N}, 23.4^{\circ} \mathrm{E}$ & 6.3 & $\mathrm{D}$ \\
\hline 06.10 .1947 & $36.8^{\circ} \mathrm{N}, 21.8^{\circ} \mathrm{E}$ & 7.0 & $\mathrm{C}$ \\
\hline 09.02 .1948 & $35.5^{\circ} \mathrm{N}, 27.2^{\circ} \mathrm{E}$ & 7.1 & $\mathrm{~F}$ \\
\hline 17.12 .1952 & $34.4^{\circ} \mathrm{N}, 24.5^{\circ} \mathrm{E}$ & 7.0 & $\mathrm{D}$ \\
\hline 12.08 .1953 & $38.2^{\circ} \mathrm{N}, 20.6^{\circ} \mathrm{E}$ & 7.2 & A \\
\hline 21.10 .1953 & $38.5^{\circ} \mathrm{N}, 20.9^{\circ} \mathrm{E}$ & 6.3 & A \\
\hline 25.04 .1957 & $36.5^{\circ} \mathrm{N}, 28.6^{\circ} \mathrm{E}$ & 7.2 & $\mathrm{G}$ \\
\hline 27.08 .1958 & $37.4^{\circ} \mathrm{N}, 20.7^{\circ} \mathrm{E}$ & 6.4 & $\mathrm{~B}$ \\
\hline 14.05 .1959 & $35.0^{\circ} \mathrm{N}, 24.7^{\circ} \mathrm{E}$ & 6.3 & $\mathrm{E}$ \\
\hline 15.11.1959 & $37.7^{\circ} \mathrm{N}, 20.6^{\circ} \mathrm{E}$ & 6.8 & $\mathrm{~B}$ \\
\hline 26.01 .1962 & $35.2^{\circ} \mathrm{N}, 22.8^{\circ} \mathrm{E}$ & 6.2 & $\mathrm{D}$ \\
\hline 10.04.1962 & $37.8^{\circ} \mathrm{N}, 20.1^{\circ} \mathrm{E}$ & 6.3 & A \\
\hline 06.07 .1962 & $37.8^{\circ} \mathrm{N}, 20,2^{\circ} \mathrm{E}$ & 6.1 & A \\
\hline 09.04 .1965 & $35.1^{\circ} \mathrm{N}, 24.3^{\circ} \mathrm{E}$ & 6.1 & $\mathrm{D}$ \\
\hline 14.01.1969 & $36.1^{\circ} \mathrm{N}, 29.4^{\circ} \mathrm{E}$ & 6.2 & $\mathrm{G}$ \\
\hline 12.06 .1969 & $34.4^{\circ} \mathrm{N}, 25.0^{\circ} \mathrm{E}$ & 6.1 & $\mathrm{E}$ \\
\hline 04.05 .1972 & $35.1^{\circ} \mathrm{N}, 23.6^{\circ} \mathrm{E}$ & 6.5 & $\mathrm{D}$ \\
\hline 17.09 .1972 & $38.3^{\circ} \mathrm{N}, 20.3^{\circ} \mathrm{E}$ & 6.3 & $\mathrm{~A}$ \\
\hline 29.11 .1973 & $35.2^{\circ} \mathrm{N}, 23.8^{\circ} \mathrm{E}$ & 6.0 & $\mathrm{D}$ \\
\hline 11.05 .1976 & $37.4^{\circ} \mathrm{N}, 20.6^{\circ} \mathrm{E}$ & 6.5 & $\mathrm{~B}$ \\
\hline 11.09 .1977 & $35.0^{\circ} \mathrm{N}, 23.1^{\circ} \mathrm{E}$ & 6.3 & $\mathrm{D}$ \\
\hline 17.01.1983 & $38.1^{\circ} \mathrm{N}, 20.2^{\circ} \mathrm{E}$ & 7.0 & A \\
\hline 21.06 .1984 & $35.4^{\circ} \mathrm{N}, 23.3^{\circ} \mathrm{E}$ & 6.2 & $\mathrm{D}$ \\
\hline 30.04 .1992 & $35.0^{\circ} \mathrm{N}, 26.7^{\circ} \mathrm{E}$ & 6.1 & $\mathrm{~F}$ \\
\hline
\end{tabular}
Hellenic trench. 


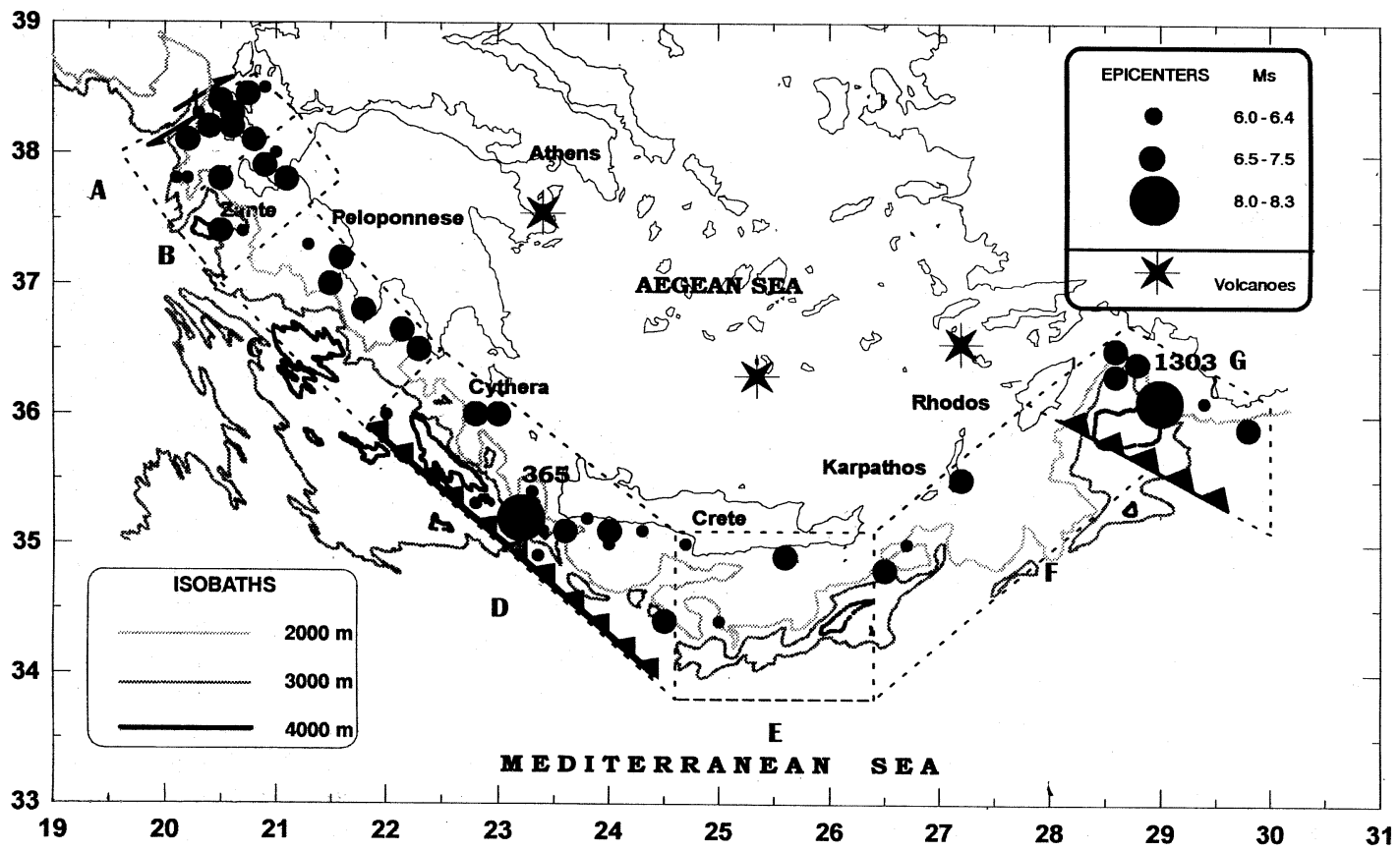

Fig. 1. Epicenters of strong shallow earthquakes along the Hellenic trench. The inferred thrust faults of the two largest known earthquakes (365 A.D., $M_{s}=8.3 ; 1303, M_{s}=8.0$ ) and the Cephalonia dextral fault are also drawn schematically.

of the region:

strike $=42^{\circ}, \operatorname{dip}=44^{\circ}$, rake $=167^{\circ}$

This is a dextral strike slip fault, with a thrust component, which strikes in a northeast-southwest direction. Such faulting in this area (see figs. 1 and 3 ) is in agreement with a southwest motion of the Aegean lithosphere.

This is a transform fault region since it connects the thrust belt along the western coast of the Northern Ionian and Adriatic sea with the thrust belt along the convex side of the Hellenic arc.

Western part of the Hellenic trench

This part includes regions B,C,D (fig. 1) for which twelve similar fault plane solutions are available (table II). From these, the following typical fault parameters were calculated:

strike $=312^{\circ}, \operatorname{dip}=19^{\circ}$, rake $=96^{\circ}$

which indicate low angle thrust faults that strike NW-SE and dip NE (fig. 3).

B) The Zante seismogenic region - This is a relatively small region where strong earthquakes with magnitudes up to about 7.0 occur frequently (Papazachos and Papazachou, 1989). The separation of this region from region $\mathrm{C}$ is mainly based on its higher seismicity. The fault type (relations (2.3), fig. 3) and the distribution of the earthquake foci (fig. 1) indicate that this region is dominated by parallel low angle thrust faults which strike in a NWSE direction and dip to NE. The length of the region parallel to the strike of the faults is no more than $70 \mathrm{~km}$ which suggests a maximum 
earthquake magnitude 7.2, according to the following formula:

$$
\log L=0.51 M_{s}-1.85
$$

between the fault length, $L$ (in $\mathrm{km}$ ), and the surface wave magnitude, $M_{s}$, which holds for earthquakes in the area of Greece (Papazachos and Papazachou, 1989).

C) Southwest of the Peloponnese seismogenic region - Five mainshocks with magnitudes between 6.5 and 7.5 occurred in this region during the last two centuries and one with magnitude between 6.0 and 6.4 since 1911 . The separation of this region from region $D$ is based on the observation that epicenters of all strong earthquakes in this region are delineated very close and along the southwestern coast of Peloponnese, while epicenters of strong earthquakes in region $D$ are scattered in a broad oceanic area (fig. 1). On the other hand, these regions are associated with different deep sea basins which are located in their southwestern parts.

The total length of the region parallel to the fault strike (relation (2.3), figs. 1 and 3 ) is $170 \mathrm{~km}$, which corresponds to a maximum earthquake with magnitude of about 8.0, according to relation (2.4). There is no written information for the occurrence of such a large earthquake in this region during historic times (since the sixth century B.C.). There is, however, some archaeological evidence that probably an earthquake of magnitude 8.0 or larger occurred in this region in about 1200 B.C. (Galanopoulos and Xanthakis, 1988).

D) West of Crete seismogenic region - This is a well defined fault region by the sea bottom topography and the spatial distribution of earthquake epicenters (fig. 1) with a length

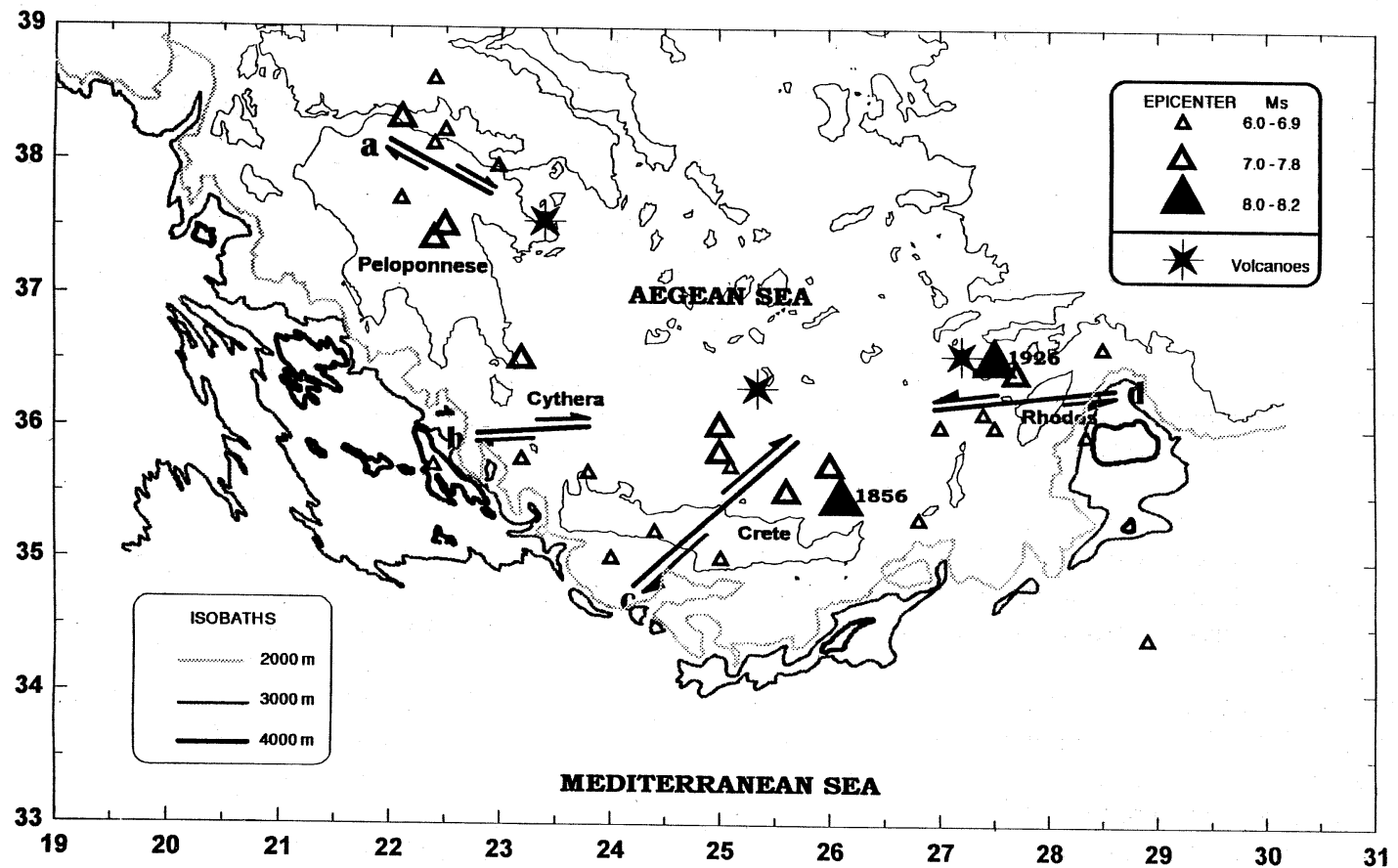

Fig. 2. Epicenters of strong intermediate depth earthquakes $(\mathrm{h}=40-100 \mathrm{~km})$ in Southern Aegean. The inferred four strike-slip faults, with a thrust component, are also drawn schematically. 


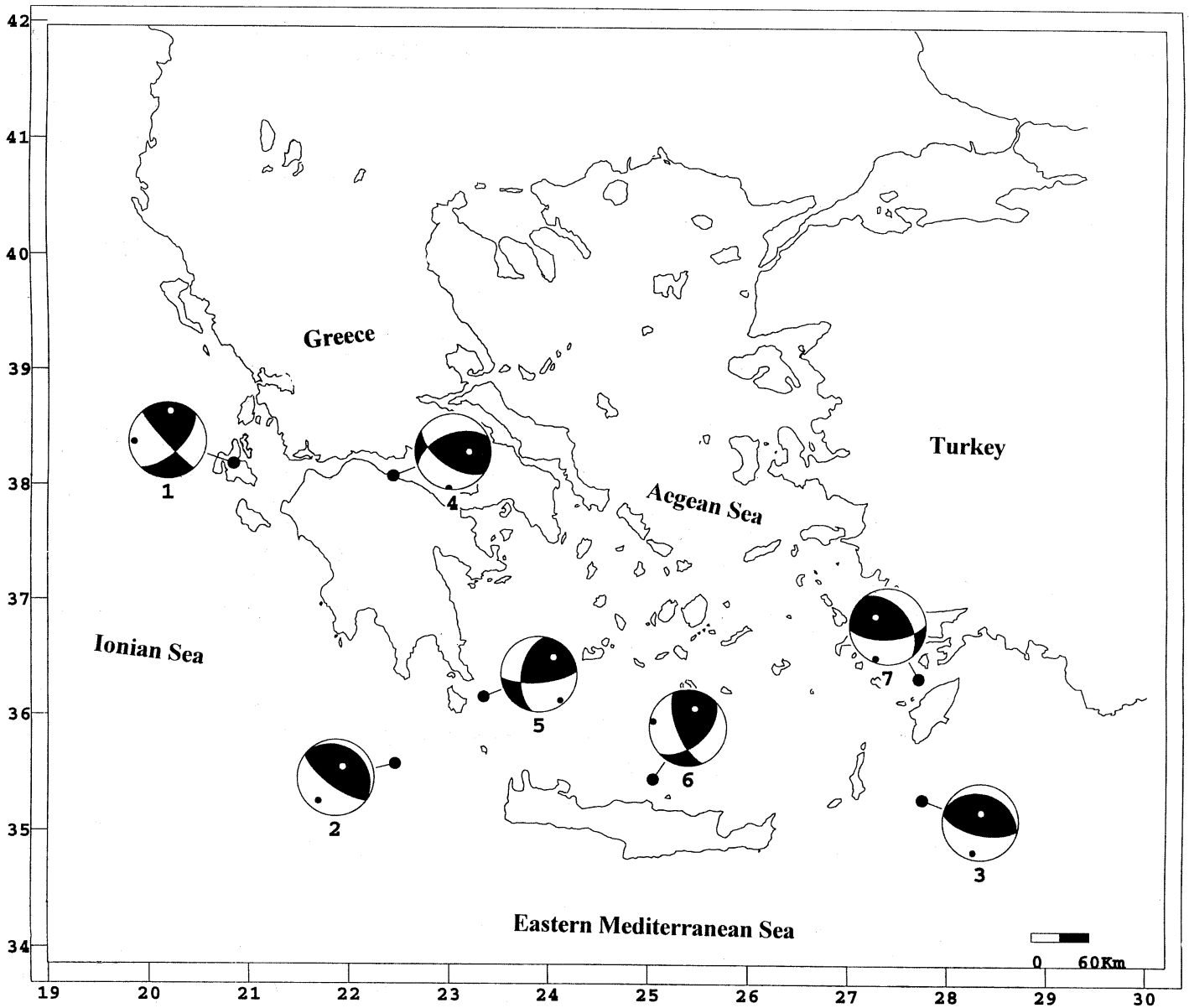

Fig. 3. Typical fault plane solutions for the shallow earthquakes $(\mathrm{h}<40 \mathrm{~km})$ along the Hellenic trench $(1,2,3)$ and for the intermediate depth earthquakes $(40 \mathrm{~km} \leq \mathrm{h} \leq 100 \mathrm{~km})$ in the concave part of the Hellenic arc $(4,5,6,7)$ (Papazachos and Kiratzi, 1995b).

equal to $300 \mathrm{~km}$. Its southeastern boundary coincides with the area where the deep sea bottom trend changes from northwest-southeast to west-east.

This region coincides with the rupture zone of the 21 July 365 A.D. large earthquake $\left(M_{s}=8.3\right)$. The epicenter of this earthquake is located near the southwestern end of Crete because a large elevation of Western Crete, which occurred during this earthquake, was recently identified and this elevation reached $9 \mathrm{~m}$ in the southwestern corner of the island (Thom- merete et al., 1981; Pirazzoli et al., 1992).

Using this value of displacement $(u=900$ $\mathrm{cm}$ ) in the following formula, in which the displacement of the fault is related to the magnitude of the corresponding earthquake for the area of Greece (Papazachos and Papazachou, 1989),

$$
\log u=0.82 M_{s}-3.71
$$

a surface wave magnitude equal to 8.1 is calculated for this earthquake. On the other hand, by 
using the length of this region parallel to the fault strike $(L=300 \mathrm{~km})$ in relation $(2.4)$ a magnitude equal to 8.5 is calculated, while macroseismic information (Papazachos and $\mathrm{Pa}-$ pazachou, 1989) indicates a value equal to 8.2 for this magnitude. The average of these three values $\left(M_{s}=8.3 \pm 0.2\right)$ was adopted as the surface wave magnitude for this earthquake, which means that this is the largest known earthquake in the Eastern Mediterranean and one of the largest known earthquakes in Western Eurasia.

Archaeological evidence presented recently (Di Vita, 1995) shows that the 365 A.D. earthquake caused destruction in Gortyn (Crete) which is at a distance $R=150 \mathrm{~km}$ from the epicenter of this earthquake. Using this value of epicenter distance and the value $M_{s}=8.3$ in the following formula which relates $R, M_{s}$ and the macroseismic intensity $I$ (in MM scale) of shallow earthquakes in Greece (Papazachos, 1992):

$M_{s}=0.46 I+1.56 \log R+0.0018 R+0.79$

an intensity $I=8.4$ is found for Gortyn, which is very reasonable.

This rupture region is clearly associated with the deep depression of the sea bottom, with water depth up to $4.7 \mathrm{~km}$, which is located southwestward of this region. This observation and the kind and size of faulting (thrust with $L=300 \mathrm{~km}$, $u=9 \mathrm{~m}$ ) explains the fact that the 21 July 365 earthquake generated the largest known tsunami in the Eastern Mediterranean which caused extensive damage along the coast of several countries (Greece, Egypt, Sicily, etc.) in this area (Guidoboni et al., 1994).

Table II. Fault plane solutions of shallow earthquakes in the Hellenic trench.

\begin{tabular}{rcccccrccc}
\hline \hline No. & Date & $\varphi^{\circ} \mathrm{N}$ & $\lambda^{\circ} \mathrm{E}$ & Strike & Dip. & Rake & $M_{s}$ & Ref. $(*)$ & Region \\
\hline 1 & Dec. 16, 1963 & 37.0 & 21.0 & 296 & 16 & 101 & 5.9 & 7 & $\mathrm{C}$ \\
2 & May 09, 1966 & 34.4 & 26.4 & 295 & 40 & 90 & 5.8 & 1 & $\mathrm{E}$ \\
3 & Mar. 28, 1968 & 37.8 & 20.9 & 354 & 34 & 137 & 5.9 & 3 & $\mathrm{~B}$ \\
4 & May 30, 1968 & 35.4 & 27.9 & 293 & 25 & 90 & 5.9 & 1 & $\mathrm{~F}$ \\
5 & Jan. 14, 1969 & 36.1 & 29.2 & 282 & 25 & 95 & 6.2 & 1 & $\mathrm{G}$ \\
6 & Apr. 16, 1969 & 35.2 & 27.7 & 301 & 30 & 109 & 5.5 & 1 & $\mathrm{~F}$ \\
7 & June 12, 1969 & 34.4 & 25.0 & 294 & 29 & 105 & 6.1 & 1 & $\mathrm{E}$ \\
8 & July 08, 1969 & 37.5 & 20.3 & 353 & 18 & 116 & 5.9 & 7 & $\mathrm{~B}$ \\
9 & May 04, 1972 & 35.1 & 23.6 & 309 & 18 & 89 & 6.5 & 4 & $\mathrm{D}$ \\
10 & Jan. 05, 1973 & 35.8 & 21.9 & 306 & 30 & 82 & 5.6 & 2 & $\mathrm{D}$ \\
11 & Nov. 29, 1973 & 35.2 & 23.8 & 316 & 10 & 90 & 6.0 & 2 & $\mathrm{D}$ \\
12 & May 11, 1976 & 37.4 & 20.4 & 335 & 14 & 106 & 6.5 & 7 & $\mathrm{~B}$ \\
13 & June 12, 1976 & 37.5 & 20.6 & 297 & 20 & 90 & 5.8 & 3 & $\mathrm{~B}$ \\
14 & Aug. 18, 1977 & 35.3 & 23.5 & 265 & 12 & 62 & 5.6 & 5 & $\mathrm{D}$ \\
15 & Sep. 11, 1977 & 34.9 & 23.0 & 320 & 30 & 90 & 6.3 & 6 & $\mathrm{D}$ \\
16 & May 15, 1979 & 34.6 & 24.5 & 253 & 17 & 65 & 5.7 & 5 & $\mathrm{~F}$ \\
17 & June 21, 1984 & 35.4 & 23.3 & 322 & 16 & 114 & 6.2 & 7 & $\mathrm{D}$ \\
18 & Apr. 21, 1985 & 35.7 & 22.2 & 269 & 36 & 71 & 5.6 & 8 & $\mathrm{D}$ \\
\hline
\end{tabular}

(*) 1: McKenzie (1972); 2: McKenzie (1978); 3: Anderson and Jackson (1987); 4: Kiratzi and Langston (1989); 5: Taymaz et al. (1990); 6: Papazachos et al. (1991); 7: Papadimitriou (1993); 8: NElS determination. 
Eastern part of the Hellenic trench

This part includes regions E, F, G (fig. 1) for which six similar fault plane solutions are available (table II). From these, the following typical fault parameters were calculated:

strike $=290^{\circ}, \operatorname{dip}=27^{\circ}$, rake $=97^{\circ}$

which indicates low angle thrust faults that strike ESE-WNW and dip NNE (fig. 3).

E) Southeast of Crete seismogenic region The eastern boundary of this region coincides with the area where the trend of the sea bottom topography changes from west-east to southwest-northeast. Only one earthquake with $M_{s} \geq 6.5$ occurred during the last two centuries and only two earthquakes with $M_{s} \geq 6.0$ have occurred since 1911 in this region. However, historical information shows that several earthquakes with magnitudes up to 7.2 occurred there during the previous four centuries ( $\mathrm{Pa}-$ pazachos and Papazachou, 1989). Also, more than fifteen smaller earthquakes $\left(M_{s}=5.5-5.9\right)$ occurred in this area during the instrumental period (since 1911).

The length of the region is much larger than the fault length of the largest earthquakes $\left(M_{s}=7.2\right)$ observed in this region. It is, therefore, probable that this region is cut by relatively small parallel faults $(L<70 \mathrm{~km})$. This is also supported by the fact that many smaller shocks occur in this region, as we have already mentioned.

F) Southeast of Karpathos seismogenic region - This region differs from the next region $G$ because region $G$ has a much higher seismicity and a different trend. The frequency of strong earthquakes $\left(M_{s} \geq 6.0\right)$ is low and no earthquake with $M_{s}>7.1$ is known in this region. However, the frequency of the smaller earthquakes $\left(M_{s}=5.5-5.9\right)$ during the instrumental period (since 1911) is high. The faults in this region (relation (2.7)) are almost normal to the trend of the coastal and deep sea topography, which indicates that present day crustal deformation in this region is different from that which formed these topographic features of tectonic origin.

The absence of any historical evidence for a large earthquake in this region, the high frequency of smaller earthquakes and the form of present day deformation indicate that this region is cut by relatively small $(L<70 \mathrm{~km})$ parallel thrust faults. The presence of large strike slip faults in this region (Jackson, 1994) cannot be excluded but it is not supported by the available seismological data.

G) East of Rhodos seismogenic region This is the region where the December 1303 large earthquake occurred $\left(M_{s}=8.0\right)$. This earthquake destroyed Rhodos and generated a gigantic tsunami which caused extensive damage in many countries of the Eastern Mediterranean (Evagelatou-Notara, 1993).

The delineation of the epicenters of several strong recent earthquakes parallel to the coast of Southwestern Turkey (fig. 1) is in accordance with the typical fault plane solution which has been determined for this region (relations (2.7), fig. 3). The length of this region is $170 \mathrm{~km}$, which is what is expected, according to relation (2.4), for an earthquake for which macroseismic data indicate a $M_{s}=8.0$ (Papazachos and Papazachou, 1989).

The deep sea bottom depression there (fig. 1) is clearly associated with this fault and explains the generation of a gigantic tsunami by the 1303 large earthquake.

\section{Faults of intermediate depth earthquakes in the Hellenic arc}

The intermediate depth earthquakes in Southern Aegean have focal depths which vary between $40 \mathrm{~km}$ and $180 \mathrm{~km}$ and are located on a Benioff zone which has an amphitheatrical shape and dips from the convex side of the arc (Eastern Mediterranean) to its concave part (Aegean sea).

In the shallow part of the Benioff zone (40-100 km), earthquakes with magnitudes up to about eight occur while in the deeper part of the zone (100-180 km) earthquakes with magnitudes up to about seven occur. 
The strong earthquakes of the deeper part $(120-180 \mathrm{~km})$ are spatially clustered in five rupture zones. These zones strike parallel to the dip direction of the front part of the descending slab and are on the same vertical planes with five corresponding shallow rupture zones (normal faults) in the volcanic arc, where the five known volcanic centers (Nisyros, Santorini, Milos, Methana, Sousaki) are located (Papazachos and Panagiotopoulos, 1993).

An attempt is made here to locate and describe the faults in the shallow part (40-100 $\mathrm{km}$ ) of the Benioff zone where the Eastern Mediterranean lithosphere underthrusts the Aegean lithosphere (Papazachos, 1990). This shallow part of the descending slab is extending at a rate of $1 \mathrm{~cm} / \mathrm{yr}$ along the dip direction and is compressed at a rate of $3 \mathrm{~cm} / \mathrm{yr}$ in a horizontal direction parallel to the arc (Kiratzi and Papazachos, 1995).

The shallow part of the Benioff zone has been separated into four seismogenic regions mainly on the basis of geometrical criteria $(\mathrm{Pa}-$ pazachos and Papaioannou, 1993). It is shown, in the present work, that each of these regions is dominated by a large fault which corresponds to the largest earthquake of the region.

Table III gives information for the following samples of intermediate depth earthquakes (40$100 \mathrm{~km}$ ) which occurred during the last two centurties in Southern Aegean:

$$
\begin{aligned}
& 1801-1995, \quad M_{s} \geq 7.5 \\
& 1889-1995, \quad M_{s} \geq 6.5 \\
& 1911-1995, \quad M_{s} \geq 6.0 .
\end{aligned}
$$

The epicenters of these earthquakes are shown in the map of fig. 2 with triangles of three sizes to denote three corresponding magnitude ranges $(6.0-6.9 ; 7.0-7.9 ; 8.0-8.2)$. Most epicenters are spatially clustered in four regions $(a, b, c, d)$ which are examined separately.

The most reliable fault plane solutions, which are available for intermediate depth earthquakes $(40-100 \mathrm{~km})$ of this area, are listed in table IV (Papazachos and Kiratzi, 1995a). a) Northeast Peloponnese seismogenic region - Three fault plane solutions are available for this region (No. 2,3,6 in table IV) from which the following typical fault parameters were derived:

strike $=124^{\circ}, \operatorname{dip}=58^{\circ}$, rake $=132^{\circ}$.

This indicates that intermediate depth earthquakes in the Benioff zone under Northeast Peloponnese occur on strike-slip dextral faults, with a reverse component, which strike in a northwest-southeast direction.

The length of this region in a direction parallel to the strike of the faults is about $100 \mathrm{~km}$, which corresponds to a magnitude 7.5 according to relation (2.4). This is the magnitude of the largest earthquake observed in this region (see table III), which means that the whole region was cut by the fault of this earthquake, while the other shocks of the region are due to ruptures of parts of this fault or of other parallel faults.

b) Cythera seismogenic region - There are two reliable fault plane solutions for this region (No. 10,12 in table IV). Based on these solutions, the following type of fault can be considered a typical one for this region:

strike $=85^{\circ}, \operatorname{dip}=72^{\circ}$, rake $=140^{\circ}$

which is a dextral strike slip fault, with a reverse component, which strikes in an almost east-west direction. The available data are limited and for this reason no estimate of the length of this fault is possible.

c) Crete seismogenic region - In this region, the largest known intermediate depth earthquake of the Eastern Mediterranean occurred $\left(12.10 .1856, M_{s}=8.2\right)$. Three fault plane solutions are available for this region (No. 4,8,9 in table IV) from which the following type of fault has been derived:

strike $=48^{\circ}, \operatorname{dip}=51^{\circ}$, rake $=150^{\circ}$.

It is a dextral strike slip fault, with a reverse component, which strikes in a northeast-south- 
Table III. Data on intermediate depth $(40-100 \mathrm{~km})$ earthquakes in the Hellenic arc.

\begin{tabular}{|c|c|c|c|c|}
\hline Date & Epicenter & $\mathrm{h}(\mathrm{km})$ & $M_{s}$ & Region \\
\hline 16.02.1810 & $35.5^{\circ} \mathrm{N}, 25.6^{\circ} \mathrm{E}$ & 90 & 7.8 & $\mathrm{c}$ \\
\hline 28.03 .1846 & $35.8^{\circ} \mathrm{N}, 25.0^{\circ} \mathrm{E}$ & 90 & 7.7 & $\mathrm{c}$ \\
\hline 12.10 .1856 & $35.6^{\circ} \mathrm{N}, 26.0^{\circ} \mathrm{E}$ & 100 & 8.2 & c \\
\hline 22.04 .1863 & $36.4^{\circ} \mathrm{N}, 27.7^{\circ} \mathrm{E}$ & 90 & 7.8 & d \\
\hline 17.07.1887 & $35.7^{\circ} \mathrm{N}, 26.0^{\circ} \mathrm{E}$ & 100 & 7.5 & $\mathrm{c}$ \\
\hline 25.08 .1889 & $38.3^{\circ} \mathrm{N}, 22.1^{\circ} \mathrm{E}$ & 80 & 7.0 & a \\
\hline 28.05 .1897 & $37.5^{\circ} \mathrm{N}, 22.5^{\circ} \mathrm{E}$ & 90 & 7.5 & $\mathrm{a}$ \\
\hline 02.06 .1898 & $37.6^{\circ} \mathrm{N}, 22.5^{\circ} \mathrm{E}$ & 90 & 7.0 & $\mathrm{a}$ \\
\hline 17.05.1908 & $35.7^{\circ} \mathrm{N}, 25.1^{\circ} \mathrm{E}$ & 90 & 6.6 & $\mathrm{c}$ \\
\hline 18.02 .1910 & $35.7^{\circ} \mathrm{N}, 23.8^{\circ} \mathrm{E}$ & 90 & 6.9 & $\mathrm{~b}$ \\
\hline 30.09 .1913 & $35.0^{\circ} \mathrm{N}, 24.0^{\circ} \mathrm{E}$ & 60 & 6.1 & $\mathrm{c}$ \\
\hline 01.08 .1923 & $35.0^{\circ} \mathrm{N}, 25.0^{\circ} \mathrm{E}$ & 90 & 6.8 & $\mathrm{c}$ \\
\hline 06.07 .1925 & $37.8^{\circ} \mathrm{N}, 22.1^{\circ} \mathrm{E}$ & 80 & 6.6 & a \\
\hline 26.06 .1926 & $36.5^{\circ} \mathrm{N}, 27.5^{\circ} \mathrm{E}$ & 100 & 8.0 & d \\
\hline 30.08 .1926 & $36.5^{\circ} \mathrm{N}, 23.3^{\circ} \mathrm{E}$ & 100 & 7.2 & $\mathrm{~b}$ \\
\hline 25.02 .1935 & $35.9^{\circ} \mathrm{N}, 25.2^{\circ} \mathrm{E}$ & 100 & 7.0 & $\mathrm{c}$ \\
\hline 18.03 .1935 & $35.3^{\circ} \mathrm{N}, 26.8^{\circ} \mathrm{E}$ & 70 & 6.4 & - \\
\hline 16.12 .1937 & $35.7^{\circ} \mathrm{N}, 23.2^{\circ} \mathrm{E}$ & 100 & 6.0 & $\mathrm{~b}$ \\
\hline 18.09 .1938 & $38.0^{\circ} \mathrm{N}, 22.5^{\circ} \mathrm{E}$ & 100 & 6.4 & a \\
\hline 21.06.1942 & $36.0^{\circ} \mathrm{N}, 27.0^{\circ} \mathrm{E}$ & 90 & 6.3 & $\mathrm{~d}$ \\
\hline 27.05 .1944 & $36.0^{\circ} \mathrm{N}, 27.5^{\circ} \mathrm{E}$ & 100 & 6.2 & $\mathrm{~d}$ \\
\hline 02.09 .1945 & $34.4^{\circ} \mathrm{N}, 28.9^{\circ} \mathrm{E}$ & 80 & 6.4 & - \\
\hline 24.07 .1948 & $35.2^{\circ} \mathrm{N}, 24.4^{\circ} \mathrm{E}$ & 80 & 6.6 & $\mathrm{c}$ \\
\hline 23.05.1961 & $36.7^{\circ} \mathrm{N}, 28.5^{\circ} \mathrm{E}$ & 70 & 6.4 & $\mathrm{~d}$ \\
\hline 28.08 .1962 & $37.8^{\circ} \mathrm{N}, 22.9^{\circ} \mathrm{E}$ & 95 & 6.8 & $\mathrm{a}$ \\
\hline 31.03 .1965 & $38.6^{\circ} \mathrm{N}, 22.4^{\circ} \mathrm{E}$ & 78 & 6.8 & $\mathrm{a}$ \\
\hline 28.11 .1965 & $36.1^{\circ} \mathrm{N}, 27.4^{\circ} \mathrm{E}$ & 73 & 6.0 & d \\
\hline 13.09 .1972 & $38.0^{\circ} \mathrm{N}, 22.4^{\circ} \mathrm{E}$ & 75 & 6.3 & $\mathrm{a}$ \\
\hline 25.08 .1990 & $35.9^{\circ} \mathrm{N}, 28.3^{\circ} \mathrm{E}$ & 70 & 6.4 & $\mathrm{~d}$ \\
\hline 21.11 .1992 & $35.7^{\circ} \mathrm{N}, 22.4^{\circ} \mathrm{E}$ & 70 & 6.3 & $\mathrm{~b}$ \\
\hline
\end{tabular}

west direction. This is supported by the distribution of the epicenters (fig. 2).

The length of this seismic region, parallel to the strike of the fault, is $220 \mathrm{~km}$, which is in good accordance to the magnitude $\left(M_{s}=8.2\right)$ of the largest earthquake of this region.

d) Rhodos seismogenic region - This is the region where the intermediate depth earthquake of 26 June $1926\left(M_{s}=8.0\right)$, which is the only so large earthquake in the Hellenic arc for which instrumental records (magnitude, etc.) are available (Papazachos and Papazachou, 1989).

Four fault plane solutions are available for this region (No. 1,5,7,11 in table IV) from which the following typical fault parameters were derived:

strike $=86^{\circ}, \operatorname{dip}=62^{\circ}$, rake $=54^{\circ}$.

This is a sinistral strike slip fault, with a thrust 
Table IV. Fault plane solutions of intermediate depth earthquakes in the Hellenic arc.

\begin{tabular}{rcccccccccc}
\hline \hline No. & Date & $\varphi^{\circ} \mathrm{N}$ & $\lambda^{\circ} \mathrm{E}$ & $M_{s}$ & $\mathrm{~h}(\mathrm{~km})$ & Strike & Dip & Rake & Ref. $(*)$ & Region \\
\hline 1 & May 23, 1961 & 36.6 & 28.5 & 6.4 & 70 & 60 & 59 & 73 & 1 & $\mathrm{~d}$ \\
2 & Aug. 28, 1962 & 37.8 & 22.9 & 6.8 & 95 & 106 & 49 & 123 & 2 & $\mathrm{a}$ \\
3 & Mar. 31, 1965 & 38.6 & 22.4 & 6.8 & 78 & 137 & 75 & 99 & 3 & $\mathrm{a}$ \\
4 & Apr. 9, 1965 & 34.9 & 24.2 & 6.1 & 51 & 63 & 76 & 157 & 4 & $\mathrm{c}$ \\
5 & Nov. 28, 1965 & 36.1 & 27.4 & 6.0 & 73 & 96 & 81 & 61 & 3 & $\mathrm{~d}$ \\
6 & Sept. 13, 1972 & 38.0 & 22.4 & 6.3 & 75 & 130 & 44 & 160 & 5 & $\mathrm{a}$ \\
7 & Nov. 28, 1977 & 36.1 & 27.8 & 5.8 & 85 & 103 & 46 & 24 & 6 & $\mathrm{~d}$ \\
8 & June 15, 1979 & 34.8 & 24.2 & 5.6 & 40 & 25 & 25 & 142 & 4 & $\mathrm{c}$ \\
9 & Mar. 19, 1983 & 35.0 & 25.3 & 5.7 & 67 & 44 & 51 & 139 & 4 & $\mathrm{c}$ \\
10 & May 22, 1984 & 36.1 & 22.8 & 5.3 & 73 & 75 & 66 & 142 & 6 & $\mathrm{~b}$ \\
11 & June 19, 1987 & 36.8 & 28.1 & 5.5 & 60 & 75 & 56 & 45 & 6 & $\mathrm{~d}$ \\
12 & Nov. 21, 1992 & 35.9 & 22.5 & 6.0 & 70 & 96 & 78 & 139 & 6 & $\mathrm{~b}$ \\
\hline
\end{tabular}

(*) 1: Ritsema (1974); 2: McKenzie (1972); 3: Papazachos et al. (1991); 4: Taymaz et al. (1990); 5: Karacostas (1988); 6: CMT Harvard determination.

component, which strikes in an almost eastwest direction. The length of the seismogenic region parallel to the strike of the fault is $L=160 \mathrm{~km}$, which is in good agreement with the instrumentally determined magnitude of the 1926 large earthquake.

\section{Discussion}

The lengths of faults of the two largest known shallow earthquakes (21 July 365, $L=300 \mathrm{~km}$; December 1303, $L=170 \mathrm{~km}$ ) as well as of the two largest known intermediate depth earthquakes (12 October 1856, $L=220$ $\mathrm{km}$; 26 June 1926, $L=160 \mathrm{~km}$ ) are estimated by the distribution of epicenters of smaller $\left(M_{s}=6.0-7.8\right)$ recent earthquakes. These lengths are in good agreement with the lengths calculated by application of relation (2.4). This relation is based on observed fault lengths of smaller shallow earthquakes $\left(M_{s}=5.8-7.4\right)$ and on the use of instrumental or macroseismic magnitudes. Also, the strikes of these four faults, determined by the clustering and lineation of the epicenters of smaller earthquakes, are in agreement with reliable fault plane solu- tions of smaller shocks $\left(M_{s}=5.3-6.8\right)$ which occurred recently in the corresponding seismogenic regions of these four large earthquakes.

These observations lead to the conclusion that shocks of smaller magnitude are spatially clustered mainly in the seismogenic regions of large earthquakes in the Hellenic arc and that these smaller shocks in each region are generated by the rupture of parts of the large fault or of parallel smaller faults.

Fault plane solutions and spatial distribution of intermediate depth earthquakes in the shallow part of the Benioff zone indicate extension along the dip direction of the zone. The direction of the deformation velocity of this extension is always normal to the strike of the zone. This observation indicates that subduction of the remnants of an old lithospheric slab, which still exists in these depths, and its coupling with the Aegean lithosphere in the shallow part of the Benioff zone generates the large intermediate depth earthquakes there.

On the contrary, fault plane solutions and spatial distribution of shallow earthquakes in the Hellenic trench indicate a compressional crustal deformation of almost constant direction with a corresponding almost constant (NW 
to WNW) strike of the thrust faults all along the trench. Taking this into consideration and the geodetic observations which indicate that the Aegean and Southwestern Anatolia move towards the Eastern Mediterranean (Jackson, 1994), we can conclude that today crustal deformation along the Hellenic trench is mainly due to overthrust of the Aegean and Southwestern Anatolia lithospheres on the Eastern Mediterranean in a roughly SW direction. Such a motion is in agreement with a dextral strike slip motion in the northwesternmost part of the trench, where the Cephalonia transform fault dominates (Scordilis et al., 1995; Papazachos et al., 1994), and with the large elevation which occurred in Western Crete during the generation of the 21 July 365 large earthquake (Thommerete et al., 1981; Pirazzoli et al., 1992).

It is probable that topography in the convex side of the Hellenic arc was first determined by a subduction process and for this reason it trends parallel to the arc. Later on, this topography was affected by the overthrust process and for this reason its present form is a result of both factors.

\section{Acknowledgements}

This research was supported by the EEC Research Project ENV4-CT96-0277.

\section{REFERENCES}

Anderson, H. and J. JACKSON (1987): Active tectonics of the Adriatic region, Geophys. J. R. Astron. Soc., 91, 937-983.

Di VITA, A. (1995): Archaeologists and earthquakes: the case of 365 A.D. earthquake, Annali di Geofisica, 38, 971-976.

Evagelatou-Notara, F. (1993): Earthquakes in Byzantium, Parousia, 24, 1-184.

Galanopoulos, A.G. and J. Xanthakis (1988): The Halley's comet a decisive agent for the Mycenean decadence, Academy of Athens Publication, 60, 411-428.

Guidoboni, E., A. Comastri and G. Traina (1984): Catalogue of Ancient Earthquakes in the Mediterranean Area up to 10th Century, Istituto Nazionale di Geofisica (SGA, Bologna), pp. 504.

JACKSON, J. (1994): Active tectonics of the Aegean region, Annu. Rev. Earth. Planet. Sci., 22, 239-271.
KARAcostas, B. (1988): Fault plane solutions of the earthquakes of the Aegean and the surrounding area, in Proceedings of the 1st Symposium on the Recent Trends in Seismology and Geophysics, Thessaloniki, July 1-3, 1988, 1-8.

KiRATZI, A.A. and C. LANGSTON (1989): Estimation of earthquake source parameters of the May 4, 1972 event of the Hellenic arc by the inversion of waveform data, Phys. Earth. Planet. Inter., 57, 225-232.

KIRATZI, A.A. and C.B. Papazachos (1995): Active deformation of the shallow part of the subducting lithospheric slab in the Southern Aegean, J. Geodyn., 19, 65-78.

LePichon, X. and J. Angelier (1979): The Hellenic arc and trench system: a key to the neotectonic evolution of the Eastern Mediterranean area, Tectonophysics, 60, $1-42$.

MCKenzIE, D. (1972): Active tectonics of the Mediterranean region, Geophys. J. R. Astron. Soc., 30, $109-185$.

McKenZIE, D. (1978): Active tectonics of the Alpine-Himalayan belt: the Aegean sea and surrounding regions, Geophys. J.R. Astron. Soc., 55, 217-254.

PAPADIMITRIOU, E.E. (1993): Focal mechanisms along the convex side of the Hellenic Arc and its tectonic significance, Boll. Geofis. Teor. Appl., 140, 401-426.

Papazachos, B.C. (1990): Seismicity of the Aegean and surrounding area, Tectonophysics, 178, 287-308.

PAPAZACHOS, B.C. and P.E. COMNINAKIS (1969/1970): Geophysical features of the Greek island arc and the Eastern Mediterranean ridge, in C.R. Seances de la Conference Reunie a Madrid, 16, 74-75.

PAPAZACHOS, B.C. and P.E. ComninAKIS (1971): Geophysical and tectonic features of the Aegean arc, J. Geophys. Res., 76, 8517-8533.

PAPAZACHOS, B.C. and A.A. Kiratzi (1995a): Type of faulting and seismic deformation in the Hellenic arc, in Proceedings XV Congress of Carpatho-Balkan Geological Association, Athens, 17-20 September 1995 (in press).

PApazachos, B.C. and A.A. Kiratzi (1995b): Typical fault parameters and crustal deformation in the area of Heraklio, Crete, publication of Geophys. Lab. Univ. Thessaloniki, No. 21, 37-55.

Papazachos, B.C. and D.G. PAnagiotopoulos (1993): Normal faults associated with volcanic activity and deep rupture zones in the Southern Aegean volcanic arc, Tectonophysics, 220, 301-308.

PApazachos, B.C. and C. PAPAIOANNOU (1993): Long term earthquake prediction in the Aegean area based on a time and magnitude predictable model, Pageoph, 140, 593-612.

Papazachos, B.C. and C.B. Papazachou (1989): The Earthquakes of Greece (Ziti Publ. Co., Thessaloniki), pp. 356 (in Greek).

PAPAZACHOS, B.C., G.F. KaraKaisis and P.M. HATZIDIMITRIOU (1994): Further information on the Cephalonia transform fault in the Ionian Sea, in Proceedings XXIV General. Assembly European Seismological Commission, Athens, 19-24 September 1994, 1, 377-384.

PAPAZACNUS, B.C., A.A. Kiratzi and E.E. PAPAdiMITRIOU (1991): Fault plane solutions for earthquakes in the Aegean area, Pageoph, 136, 405-420. 
PAPAZACHOS, C.B. (1992): Anisotropic radiation modelling of macroseismic intensities for estimation of the attenuation structure of the upper crust in Greece, Pageoph, 138, 445-469.

PAPAZACHOS, C.B. and A.A. Kiratzi (1992): A formulation for reliable estimation of active crustal deformation and its application to Central Greece, Geophys. J. Int., 111, 424-432.

Pirazzoli, P.A., J. Ausseil-Badie, P. Girese, E. HadjDAKI and M. ARNOLD (1992): Historical environmental changes at Phalasarna Harbor, West Crete, Geoarchaeology, 7, 371-392.

Ritsema, A. (1974): The earthquake mechanisms of the Balkan region, R. Netherl. Meteorol. Inst., De Bilt, Sci. Rep., 74-4.

Scordilis, E.M., G.F. Karakaisis, B.G. Karacostas,
D.G. Panagiotopoulos, P.E. Comninakis and B.C. PAPAZACHOS (1985): Evidence for transform faulting in the Ionian Sea: the Cephalonia island earthquake sequence of 1983, Pageoph, 123, 388-397.

TAYMAZ, T., J. JACKSON and R. WESTAWAY (1990): Earthquake mechanisms in the Hellenic Trench near Crete, Geophys. J. Int., 102, 695-731.

Thommerete, Y., J. Thommerete, J. LABOrel, L.F. Montaggioni and P.A. Pirazzoli (1981): Late Hollocene shoreline changes and seismotectonic displacements in Western Crete, Z. Geomorphol. Suppl., 40, 127-149.

(received November 6, 1995; accepted June 26, 1996) 